\title{
Observations on the Association of Serum histamine, Interleukins and Other Serum Biochemical Values with Severity of Pruritus in Chronic Hemodialysis Patients
}

\author{
Nabaa Kamal Al Shafei ${ }^{1 *}$ and Abdelfattah Nour ${ }^{2}$
}

${ }^{1}$ Department of Biochemistry, Bahri University, Faculty of Veterinary Medicine, Sudan

${ }^{2}$ Department of Basic Medical Sciences, School of Veterinary Medicine, Purdue University, USA

\begin{abstract}
Pruritus is one of the most bothersome symptoms in patients on maintenance hemodialysis (HD), however little progress is seen in our understanding of its pathogenesis and the association of different serum biochemical values with its severity. The aim of this study was to evaluate pruritus in HD patients in Benha hospital, Egypt, and to correlate its presence and severity with relevant clinical and laboratory parameters. Fifty Hemodialysis patients were randomly selected from a total of ninety nine patients receiving chronic hemodialysis. An elaborate survey, that included interviews, was conducted to identify patients with pruritus. Twenty one patients on maintenance HD have uremic pruritus (UP) out of fifty patients were enrolled in the study. Blood samples from hemodialysis patients and hemodialysis patients with pruritus were taken during the dialysis. Serum samples were kept frozen at $-20^{\circ} \mathrm{C}$ until chemical and immunoassay were performed. Some relevant clinical and laboratory parameters including $\mathrm{Na}, \mathrm{K}, \mathrm{IL}-2$, IL-6, cortisol and histamine were evaluated. In 21 patients $(42 \%)$ pruritus intensified during dialysis. There were significant increase $(P<0.05)$ in the serum levels of BUN, Cr, IL-2, IL-6, and there was a highly significant increase in histamine and cortisol. The results of this investigation showed that several serum biochemical values (cortisol, histamine, IL-2 and IL-6) had increased significantly in uremic patients compared to hemodialysis patients, and healthy patients. The results of this investigation suggest that many factors may have important role in pathogenesis and progression of uremic pruritus from mild to severe. The association of histamine, cortisol, IL-2 and IL-6 are evident; compromised immune function and electrolytes disturbances are related to impaired kidney function and the accumulation of uremic toxins. Further research is needed to elucidate the main causes of UP, and the predictive value of serum biochemical components. The effect of the dialyzing membrane should be factored in any such investigation. The results of our study point out to the potential important role of both IL-2 and IL-6 in UP. Further studies are needed to investigate the contribution of histamine, IL-2 and IL-6, monocytes, and basophils on the development and severity of uremic pruritus, and the possible role of anti-IL-2 and IL-6 receptor antibodies in treatment of severe pruritus. Further, research using a proteomic approach to identify itching-related uremic toxins, and the biomarkers that can be used for early detection of PU is urgently needed.
\end{abstract}

Keywords: Cortisol; Histamine; Antibodies; Immunoassay; Hemodialysis; Inflammatory; Toxins

\section{Introduction}

Uremic pruritus is a common and sometimes severe complication of chronic renal failure. Itch affects $50-90 \%$ of patients undergoing hemodialysis, and $25 \%$ of patients with pre-terminal chronic renal failure. The mechanism underlying uremic pruritus is poorly understood; although possibilities include histamine, proteases, interleukin-2 (IL-2) and TNF- produced by skin mast-cells, substance $\mathrm{P}$, neuropathy and neurological changes, high levels of $\mathrm{Ca}, \mathrm{P}, \mathrm{PTH}, \mathrm{Al}$, $\mathrm{Mg}$, divalent ion abnormalities, inflammation, or some combination of these. Two hypotheses for the underlying pathophysiological mechanisms of uremic pruritus have been proposed, the immunohypothesis, and opioid hypothesis [1]. The pruritus were strongly associated with diminished health-related quality of life in multiple domains, including mood, sleep, and social relations [2]. Cytokines are essential mediators of immune response and inflammatory reactions. Patients with chronic renal failure (CRF) commonly present with abnormalities of immune function related with impaired kidney function and the accumulation of uremic toxins in addition to bioincompatibility of dialyzer membranes. During a hemodialysis (HD) session, cytokines are released mainly by monocytes activated by endotoxin-type compounds in dialyzer fluid, complement factors and direct contact with dialyzer membrane [3]. Cytokines are the essential mediators of immune response and the inflammatory reactions. They are released by immune cells in response to numerous antigens, bacterial polysaccharides and lectins [4]. Patients with chronic renal failure commonly present with abnormalities of immune function strictly correlated with abnormalities of immune cell reactivity, phenotype alternations of receptors and altered expression of cell surface receptors. These abnormalities are caused by impaired excretory function of kidneys and the accumulation of uremic toxins in addition to bio incompatibility of dialyzer membranes [5]. The present work aimed to evaluate the association of serum histamine, Interleukins and other Serum biochemical values with severity of pruritus in chronic hemodialysis Patients in Egypt.

\section{Materials and Methods}

\section{Patients}

Fifty Hemodialysis patients were randomly selected from a total

*Corresponding author: Nabaa Kamal Al Shafei, Department of Biochemistry, College of Veterinary Medicine, University of Bahri, Khartoum, Sudan, Tel: +249122410042; E-mail: nabaak@yahoo.com

Received December 03, 2015; Accepted December 29, 2015; Published January 10,2016

Citation: Shafei NKA, Nour A (2016) Observations on the Association of Serum histamine, Interleukins and other Serum Biochemical Values with Severity of Pruritus in Chronic Hemodialysis Patients. J Nanomed Nanotechnol 7: 345 doi:10.4172/2157-7439.1000345

Copyright: (c) 2016 Shafei NKA, et al. This is an open-access article distributed under the terms of the Creative Commons Attribution License, which permits unrestricted use, distribution, and reproduction in any medium, provided the original author and source are credited. 
Citation: Shafei NKA, Nour A (2016) Observations on the Association of Serum histamine, Interleukins and Other Serum Biochemical Values with Severity of Pruritus in Chronic Hemodialysis Patients. J Nanomed Nanotechnol 7: 345. doi:10.4172/2157-7439.1000345

Page 2 of 6

of ninety nine patients receiving chronic hemodialysis through venous catheter at the Artificial Kidney Unit of Benha University's hospital, Egypt. An elaborated survey, that included patient's interviews, was conducted to identify patients with pruritus for this study. Blood samples were drawn during the first 15 minutes of dialysis from each of the twenty one $(\mathrm{n}=21)$ patients who had confirmed pruritus. Blood samples were also obtained from the control group.

\section{Study design}

The patients under study were assigned to one of three groups:

1. Control one group included patients with no chronic renal failure.

2. Control two group, included chronic renal failure patients undergoing hemodialysis, but have no pruritus.

3. Pruritus group, included chronic renal failure patients undergoing hemodialysis, who have pruritus.

Further, the degree of pruritus was classified according to a visual analogous scale as mild, moderate or severe pruritus:

1. Mild pruritus patients $(n=6)$ had stings of itching all over their body or in parts of their body when the patients were receiving blood transfusion.

2. Moderate pruritus patients $(n=8)$ were those who had desire to scratch sporadically, and had lesions in one or two parts of the body.

3. Severe pruritus patients $(n=7)$ had constant itching, and they indicated that this itching had been disturbing their sleep; and they appeared to have skin lesions all over their body.

\section{Blood samples}

Blood samples were drawn, during the first 15 minutes of dialysis, from each of the twenty one $(n=21)$ patients who had confirmed pruritus. Blood samples were also obtained from six $(n=6)$ chronic hemodialysis patients without pruritus (control). Blood samples were drawn from the arterial end of the vascular access into $3 \mathrm{ml}$ sterile test tubes. Samples were allowed to coagulate at room temperature for 30 minutes, then centrifuged at 3000 revolutions per minute (RPM) for 10 minutes. The serum samples were separated and kept frozen at $-20^{\circ} \mathrm{C}$ for chemical and immunoassays. Laboratory assays performed on each sampled included the following parameters: blood urea nitrogen (BUN), creatinine $(\mathrm{Cr})$, sodium $(\mathrm{Na})$, potassium $(\mathrm{K})$, IL-2, IL-6, Histamine and cortisol. Data on the levels of Urea (Ur), Creatinine (Cr), Sodium (Na) and Potassium $(\mathrm{K})$ in each patient's blood were obtained from the most recent records of routine analysis laboratory of the Artificial kidney Unit of Benha's hospital. The procedure used for measuring the above mentioned serum biochemical constituents involved kinetic methods and reading of the samples using spectrophotometer as follows: Urea was measured by urea UV method described by Patton and Crouch [6]. On the other hand, creatinine was determined by the Jaffe Colorimetric End point method as outlined by Houort [7]. The colorimetric determination of serum sodium and potassium were done according to the method of Trinder [8] and Terri and Sesin [9], respectively. Human IL- ELISA Kit was used for the quantitative determination of human Interleukins- (IL-) concentrations in serum was described by Rubin [10]. Cortisol was determined according to the method of Check [11]. On the other hand, histamine ( $ß$-imidazolethylamine) level in plasma was determined according to the method of Hermann et al. [12].

\section{Statistical analysis}

The Results were expressed as means +/- standard error of the mean $((\mathrm{X} \pm \mathrm{S} . \mathrm{E})$ and were compared using the F-test analysis of variance (ANOVA) following the method described by Snedecor and Cochran [13].

\section{Results}

The results for BUN and creatinine $(\mathrm{mg} / \mathrm{dl})$ are presented in Table 1, and illustrated in Figures 1 and 2. Table 1 and Figures 1 and 2 show that BUN and creatinine increased significantly in serum obtained from both hemodialysis patients and pruritus patients compared to the control group. On the other hand, the severe pruritus patients had a highly significant increase in serum urea and creatinine compared with that of mild and moderate pruritus patients. It could be observed that hemodialysing patients with or without pruritus has higher BUN and creatinine than the control group with no renal failure.

On the other hand, data presented in Table 2 and Figure 3 revealed a significant $(\mathrm{P}<0.05)$ decrease in sodium levels (hyponatremia) in hemodialysis control patients and pruritus patients compared to control group that has no renal failure. At the meantime, mild pruritus group has the lowest serum sodium level $(60.42 \pm 16.54 \mathrm{mg} /$ $\mathrm{dl})$, while the moderate group has the highest $(85.11 \pm 11.96 \mathrm{mg} / \mathrm{dl})$ sodium serum levels. The hemodialysis no pruritus group and the severe pruritus group had similar serum sodium levels. When serum potassium $(\mathrm{mg} / \mathrm{dl})$ of control group and hemodialysis with and without pruritus were compared in Table 2 and Figure 4, it was observed that the serum potassium levels significantly increased (hyperkalemia) in

\begin{tabular}{|c|c|c|c|c|c|}
\hline \multirow[b]{2}{*}{$\begin{array}{l}\text { Patient } \\
\text { Parameters }\end{array}$} & \multirow{2}{*}{$\begin{array}{l}\text { Control } \\
\text { normal } \\
\text { patients } \\
\text { group }\end{array}$} & \multicolumn{4}{|c|}{ Haemodialysis patients group } \\
\hline & & $\begin{array}{l}\text { Without } \\
\text { pruritus }\end{array}$ & $\begin{array}{c}\text { Mild } \\
\text { pruritus }\end{array}$ & $\begin{array}{l}\text { Moderate } \\
\text { pruritus }\end{array}$ & $\begin{array}{l}\text { Severe } \\
\text { pruritus }\end{array}$ \\
\hline Urea (mg/dl) & $20.5 \pm 4.45^{d}$ & $83.67 \pm 21.67^{b}$ & $56 \pm 39.47^{c}$ & $79.22 \pm 10.74^{b}$ & $88.00 \pm 18.90^{a}$ \\
\hline $\begin{array}{l}\text { Creatinine } \\
\text { (mg/dl) }\end{array}$ & $0.74 \pm 0.15^{c}$ & $5.08 \pm 1.69^{b}$ & $3.97 \pm 1.30^{b}$ & $4.88 \pm 0.93^{b}$ & $6.36 \pm 1.47^{a}$ \\
\hline
\end{tabular}

Reference ranges are presented as mean \pm S.E.

Means values with different superscript letters in the same row are significantly different $(P<0.05)$

Table 1: Serum urea and creatinine concentration in normal control and hemodialysis patients with and without pruritus.

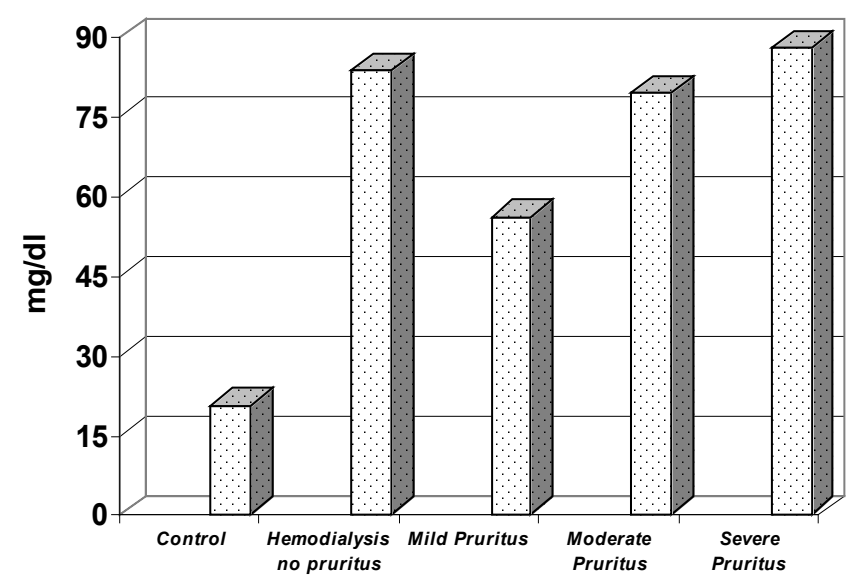

Figure 1: Comparisons of serum Urea concentration in normal control and hemodialysis patients with and without pruritus. 
Citation: Shafei NKA, Nour A (2016) Observations on the Association of Serum histamine, Interleukins and Other Serum Biochemical Values with Severity of Pruritus in Chronic Hemodialysis Patients. J Nanomed Nanotechnol 7: 345. doi:10.4172/2157-7439.1000345

Page 3 of 6

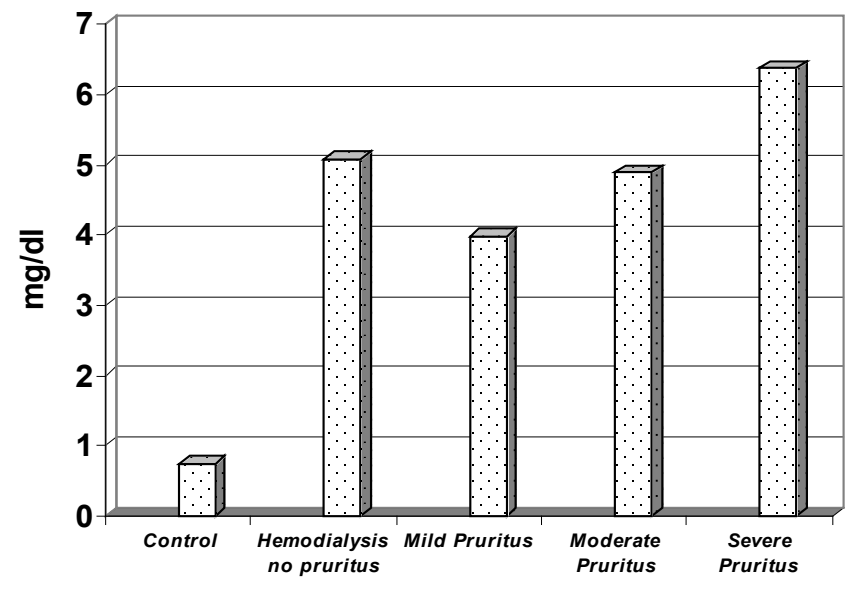

Figure 2: Comparisons of serum creatinine concentration in normal control and hemodialysis patients with and without pruritus.

\begin{tabular}{|c|c|c|c|c|c|}
\hline \multirow[b]{2}{*}{$\begin{array}{l}\text { Patient } \\
\text { Parameters }\end{array}$} & \multirow{2}{*}{\begin{tabular}{|l|} 
Control \\
normal \\
patients \\
group
\end{tabular}} & \multicolumn{4}{|c|}{ Hemodialysis patients group } \\
\hline & & $\begin{array}{l}\text { Without } \\
\text { pruritus }\end{array}$ & $\begin{array}{c}\text { Mild } \\
\text { pruritus }\end{array}$ & $\begin{array}{c}\text { Moderate } \\
\text { pruritus }\end{array}$ & $\begin{array}{l}\text { Severe } \\
\text { pruritus }\end{array}$ \\
\hline $\begin{array}{l}\text { Sodium } \\
\text { (mg/dl) }\end{array}$ & $120 \pm 24.09^{a}$ & $71.67 \pm 16.65^{c}$ & $60.42 \pm 16.54^{d}$ & $85.11 \pm 11.96^{b}$ & $78.25 \pm 12.50^{\circ}$ \\
\hline $\begin{array}{l}\text { Potassium } \\
\text { (mg/dl) }\end{array}$ & $3.91 \pm 0.8^{d}$ & $7.46 \pm 2.42^{b}$ & $5.32 \pm 1.58^{c}$ & $8.53 \pm 1.16^{a}$ & $8.98 \pm 1.36^{a}$ \\
\hline
\end{tabular}

Reference ranges are given as Mean $\pm \mathrm{S}$. $\mathrm{E}$.

Mean values with different superscripts in the same row are significantly different at $(\mathrm{P}<0.05)$

Table 2: Serum Sodium and potassium concentration in normal control and hemodialysis patients with and without pruritus.

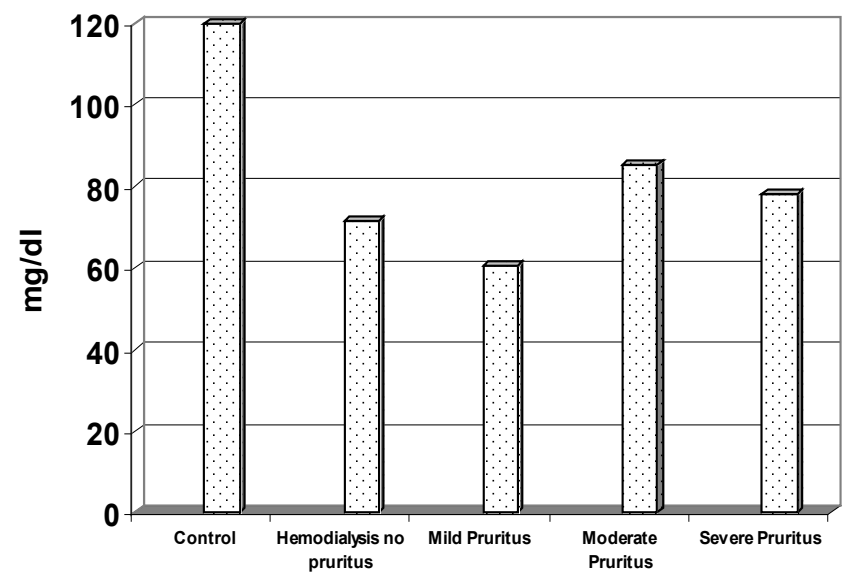

Figure 3: Comparisons of serum sodium concentration in normal control and hemodialysis patients with and without pruritus.

the hemodialysis patients compared to the control group that has no renal failure. Within the hemodialysis groups, the moderate and severe pruritus patients had the highest potassium levels compared to their hemodialysis control. The mild pruritus group had lower potassium in their serum compared with their hemodialysis control.

From Table 3 and Figure 5, it could be observed that, compared to the control group serum histamine $\mathrm{nmol} / \mathrm{ml}$ increased significantly $(\mathrm{p}<0.05)$ in hemodialysis patients and the pruritus patients, except for the mild pruritus group. Pruritus patients had higher serum histamine levels than the hemodialysis control and this increase became highly significant $(\mathrm{p}<0.05)$ in severe pruritus patients compared to other groups. On the other hand, the mild pruritus group had the lowest serum histamine levels, which was not different from the hemodialysis control. Therefore, it seems that serum histamine levels increase as the severity of pruritus increases.

Serum cortisol level, as shown in Table 3 and Figure 5, increased significantly $(\mathrm{P}<0.05)$ in both pruritus patients and their haemodialysis control when compared to that in the non-renal failure control group. Within the pruritus groups, those patients with moderate pruritus had higher serum cortisol level than the other two pruritus groups which are not different $(\mathrm{P}>0.05)$ from each other.

Table 4 presents the mean and S.E of serum IL-2 and IL-6 (IU/ $\mathrm{ml}$ ) in the non-renal failure control, hemodialysis patients with no pruritus, and the pruritus patients; Figures 6-8 illustrates graphically the data. It could be concluded that there was non- significant increase in serum IL-2 levels in hemodialysis patients and pruritus patients groups compared with the non-renal failure control. It was clear that, in both renal failure and pruritus group IL-6 serum levels of the pruritus patients groups, and their hemodialysis control were significantly higher $(\mathrm{P}<0.05)$ when compared with that in non-renal failure control patients. Moderate pruritus patients revealed high significant increase in IL-6 compared to other groups.

\section{Discussion}

Uremic pruritus remains a serious problem that interferes with the quality of life of dialysis patients. In addition, severe uremic pruritus is associated with poor outcomes in chronic HD patients as suggested

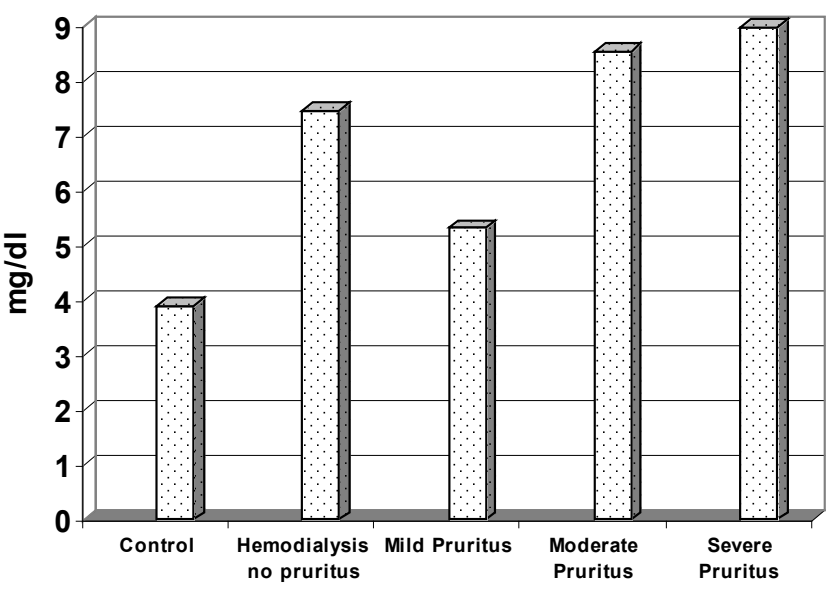

Figure 4: Comparisons of serum potassium concentration in normal control and hemodialysis patients with and without pruritus.

\begin{tabular}{|l|l|l|l|l|l|}
\hline & $\begin{array}{l}\text { Control } \\
\text { normal } \\
\text { Patient } \\
\text { parameters }\end{array}$ & \multicolumn{3}{|l|}{ Haemodialysis patients group } \\
\cline { 2 - 4 } & group & $\begin{array}{l}\text { Without } \\
\text { pruritus }\end{array}$ & $\begin{array}{l}\text { Mild } \\
\text { pruritus }\end{array}$ & $\begin{array}{l}\text { Moderate } \\
\text { pruritus }\end{array}$ & $\begin{array}{l}\text { Severe } \\
\text { pruritus }\end{array}$ \\
\hline $\begin{array}{l}\text { Histamine } \\
\text { (mg/dl) }\end{array}$ & $1.50 \pm 0.33^{\mathrm{d}}$ & $10.97 \pm 3.2^{\mathrm{c}}$ & $8.72 \pm 3.51^{\mathrm{c}}$ & $14.21 \pm 2.66^{\mathrm{b}}$ & $19.99 \pm 3.94^{\mathrm{a}}$ \\
\hline $\begin{array}{l}\text { Cortisol } \\
\text { (mg/dl) }\end{array}$ & $7.79 \pm 1.78^{\mathrm{d}}$ & $35.48 \pm 11.09^{\mathrm{c}}$ & $58.35 \pm 15.32^{\mathrm{b}}$ & $73.81 \pm 11.76^{\mathrm{a}}$ & $58.38 \pm 10.37^{\mathrm{b}}$ \\
\hline
\end{tabular}

Reference ranges are given as Mean $\pm \mathrm{S}$. $\mathrm{E}$.

Mean values with different superscripts in the same row are significantly different at $(\mathrm{P}<0.05)$

Table 3: Serum histamine and cortisol concentrations in normal control and hemodialysis patients with and without pruritus. 


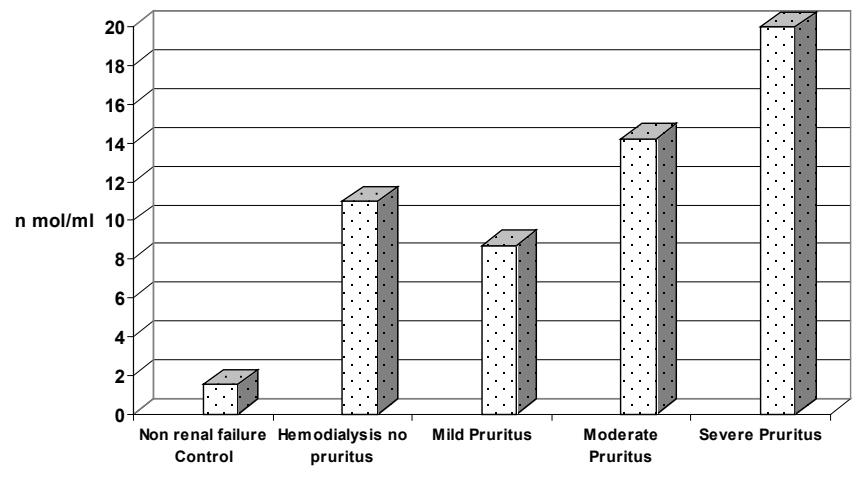

Figure 5: Comparisons of serum histamine concentration in normal control and hemodialysis patients with and without pruritus.

\begin{tabular}{|c|c|c|c|c|c|}
\hline \multirow[b]{2}{*}{$\begin{array}{l}\text { Patient } \\
\text { Parameters }\end{array}$} & \multirow{2}{*}{$\begin{array}{l}\text { Control } \\
\text { normal } \\
\text { patients } \\
\text { group }\end{array}$} & \multicolumn{4}{|c|}{ Hemodialysis patient groups } \\
\hline & & $\begin{array}{l}\text { Without } \\
\text { pruritus }\end{array}$ & $\begin{array}{c}\text { Mild } \\
\text { pruritus }\end{array}$ & $\begin{array}{l}\text { Moderate } \\
\text { pruritus }\end{array}$ & $\begin{array}{l}\text { Severe } \\
\text { pruritus }\end{array}$ \\
\hline $\begin{array}{l}\text { IL-2 } \\
\text { (pg/ml) }\end{array}$ & $0.14 \pm 0.03^{a}$ & $0.87 \pm 0.27^{a}$ & $0.69 \pm 0.27^{a}$ & $1.03 \pm 0.29^{a}$ & $0.97 \pm 0.21^{a}$ \\
\hline $\begin{array}{l}\text { IL-6 } \\
\text { (pg/ml) }\end{array}$ & $5.71 \pm 1.15^{c}$ & $12.79 \pm 2.83^{\mathrm{a}, \mathrm{b}}$ & $9.90 \pm 3.07^{b}$ & $16.02 \pm 2.26^{a}$ & $13.58 \pm 2.60^{\mathrm{a}, \mathrm{b}}$ \\
\hline
\end{tabular}

Reference ranges are given as Mean $\pm \mathrm{S}$. E.

Mean values with different superscripts in the same row are significantly different at $(\mathrm{P}<0.05)$

Table 4: Serum IL-2 and IL-6 concentration in normal control and hemodialysis patients with and without pruritus.

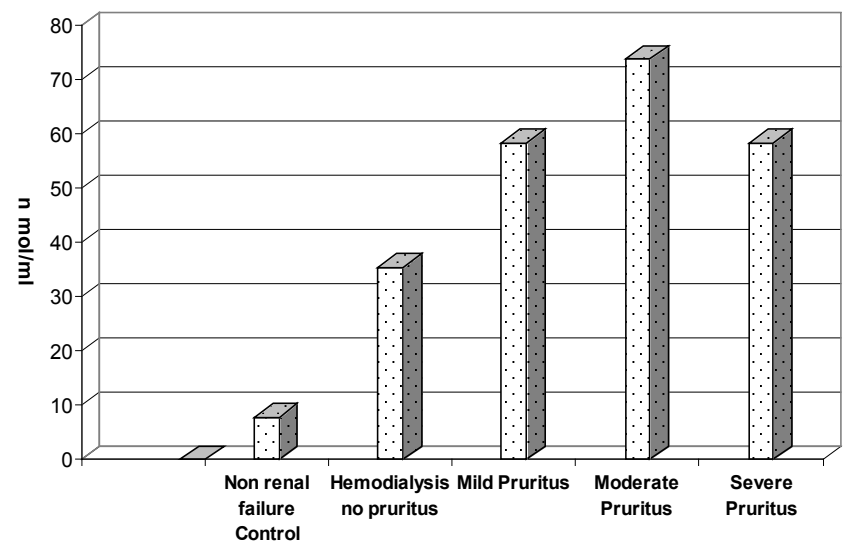

Figure 6: Comparisons of serum Cortisol concentration in normal control and hemodialysis patients with and without pruritus.

by Narita et al. [14]. Our results showed there was an increase in blood urea nitrogen, and serum creatinine levels in hemodialysing patients, may suggest renal damage, as reported by zahran et al. who concluded that the significantly $(\mathrm{P}<0.05)$ increased serum creatinine levels indicate development of renal failure. Plasma levels of substances such as urea and creatinine start to show significant increases only after total GFR has decreased to $50 \%$, when the renal reserve has been exhausted $[15,16]$. Many reports had suggested that the plasma creatinine value will approximately double with a $50 \%$ reduction in GFR. In addition, a rise in plasma creatinine from a baseline value of $0.6 \mathrm{mg} / \mathrm{dL}$ to $1.2 \mathrm{mg} /$ $\mathrm{dL}$ in a patient. Although the underling mechanism of this increase is not clear, some evidence suggests that this increase could be attributed to the basic functions of the kidneys as the site of fluid and electrolyte regulation, and waste-product elimination [17]. The results observed in this study are consistent with those reported in the literature.

The highly significant $(\mathrm{P}<0.05)$ increase in level of serum potassium (hyperkalemia) in pruritus patients and their hemodialysis control are in agreement with Giebisch and Wang [18] and Bleyer et al. [19] who noticed that potassium retention remains one of the major causes of death in the dialysis patients. Also Rose and Post [20] indicated that oliguric patients tend to develop hyperkalemia, especially if they are on a high potassium diet, had decreased aldosterone levels, or suffered from increased tissue breakdown. Therefore, the increased serum potassium could be attributed to the fact that renal failure has caused a loss of the function as organ that has a crucial role $\mathrm{K}^{+}$homeostasis. Understandably, hyperkalemia can be expected with advanced renal failure [21]. On the other hand, the highly significant decrease in serum sodium levels (hyponatremia) in pruritus patients and their haemodialysis control group is in agreement with the results obtained by Rosa et al. [22] who recognized that, the lack of free water excretion in advanced renal failure can lead to the retention of water consumed by the patient with the concomitant development of hyponatremia. However, Szepietowski et al. [23] argued that the decreased serum sodium may be due to uremic toxins, which are bound to the sodium/ potassium ATP, and this would eventually cause accumulation of sodium inside the cells and its loss.

Serum histamine levels significantly increased in haemodialysis patients, and a highly significant increase was observed in severe pruritus patients indicating a positive association between histamine levels and severity of pruritus. These results are supported by the findings of a similar study conducted by Dugas-Breit et al. [24] who concluded that histamine released by skin mast of uremic patients is an important mediator for itching. They indicated that mast cells in the skin and increased serum histamine levels were observed in uremic patients. On the other hand, similar results were reported by Zhang and Lindup [25] who concluded that histamine levels in the serum significantly increased in severe uremic pruritus patients with chronic renal failure. It is interesting to note we observed that not only severe pruritus group had the highest serum histamine but also the highest IgE levels of all groups (Unpublished data). Also in this study we found an association between the increase in production of blood histamine and the increased basophils count (results not shown) similar to that found by Mukai et al. [26]. Histamine is produced predominantly by mast cells, but also is elaborated by basophils as indicated by Sokol et al. [27] Basophils have long been associated with allergy [28], however their role in development and progress of pruritus remains unclear. The increased blood histamine levels in uremic patients observed in this study are also similar to those found by Ståhle-Bäckdahl et al. [29] who concluded that histamine concentrations are much higher in uremic patients with itch than in non-uremic or non-itching patients. Interestingly, and in contrast to our findings and recent reports in the literature, Urbonas et al. [30] argued that there was no correlation could be found between the severity of the itching and the plasma histamine levels. It worth mentioning here that an intradermal injection of histamine uremic patients suffering from itching causes more intense localized itch than in either non-itching uremic patients or healthy individuals, suggesting that an increased sensitivity to histamine. Nevertheless, despite the increased levels of histamine in pruritus patients, most studies have failed to show any correlation between histamine levels and uremic pruritus [31]. Furthermore, while some studies showed reduction of uremic pruritus following an antihistaminic treatment, investigations could not confirm the benefits of the treatment [32]. Some reports [33] concluded that histamine alone may not the sole factor responsible for 


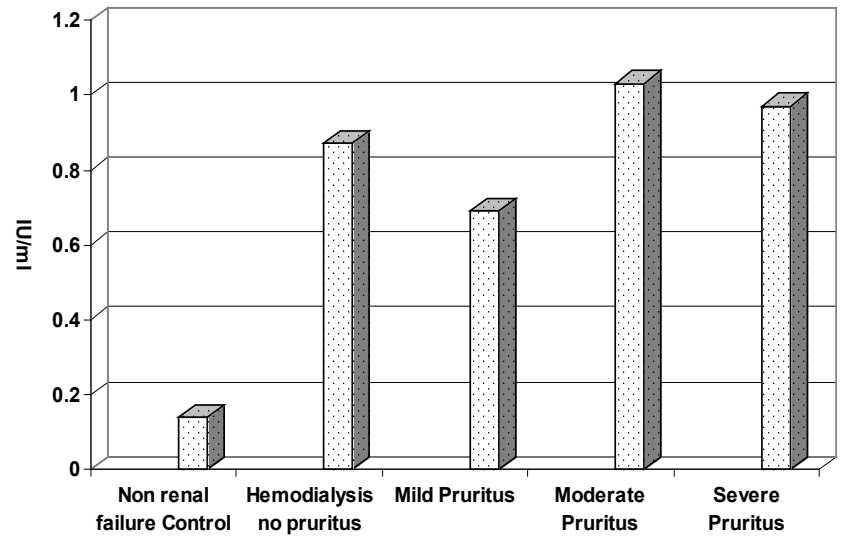

Figure 7: Comparisons of serum IL-2 concentration in normal control and hemodialysis patients with and without pruritus.

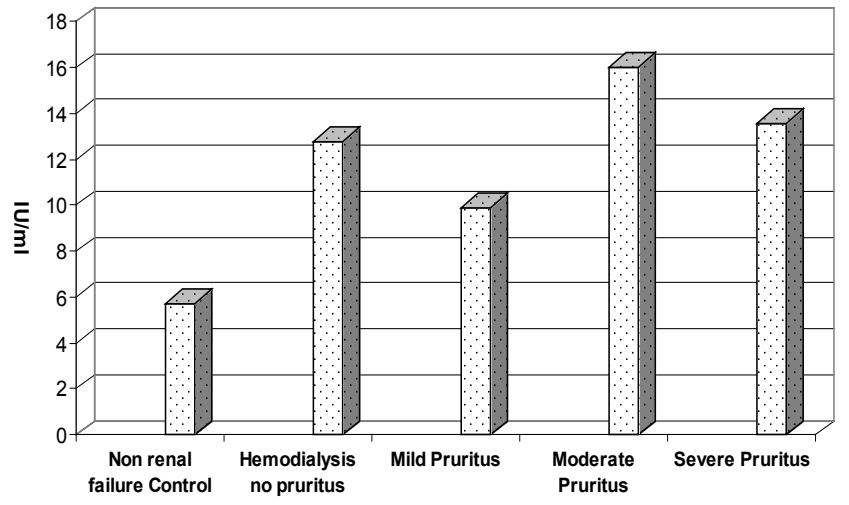

Figure 8: Comparisons of serum IL-6 concentration in normal control and hemodialysis patients with and without pruritus.

the severity of uremic pruritus. Richardson [34] concluded that plasma histamine levels were noticeably increased but this was not correlated with the severity of pruritus. The results of this study documented the increased histamine levels in pruritus patients and the histamine levels increased with increasing severity of pruritus.

Cortisol levels in pruritus patients were higher than that of the non-renal failure control, indicating that renal failure is a stressful condition that lead to substantial increase (five times) in the cortisol levels. In addition, pruritus added an additional stress that resulted in eight times increase compared to the non-renal failure control, and 1.5 to 2 times than that of the hemodialysis control group. Tao [35] commented that basal serum and urinary cortisol levels increased in pruritus patients, and that this substantial increase in blood cortisol causes pruritus. The observed increase of serum cortisol levels in hemodialysis patients and in pruritus patients could be attributed to the stress factors as stated by Rosman [36] who proved that, cortisol (hydrocortisone), a glucocorticoid produced by the adrenal gland, was released in response to stress. Fallahzadeh [37] suggested that the increased cortisol levels are attributed to the inability of the kidney to excrete cortisol and its water soluble metabolites. As a result, the serum half-life of cortisol becomes prolonged in advanced renal failure.

The non-significant $(\mathrm{P}>0.05)$ increase in serum IL-2 in pruritus patients and their hemodialysis control compared to control observed in this study confirmed the findings of Vink et al. [38] who stated that, serum levels of IL-2 have been demonstrated to be higher in hemodialysis patients with itch (uremic pruritus) compared to those without itch. As a proof, therapeutic measures that inhibit IL-2, such as Ultraviolet therapy, have been demonstrated to be effective in treatment of uremic pruritus. In addition, direct injection of IL-2 into skin of healthy subjects as well as those with atopic dermatitis has resulted in itching [38]. However, in this study there was a numerical increase in IL-2 in the moderate and severe pruritus group compared to their hemodialysis control. These differences between the hemodialysis and pruritus groups were not statistically significant. However, there is a 5-7 increase in IL-2 in the pruritus groups compared to the non-renal failure control, suggesting a response to inflammation and perhaps an immune reaction. Smith [39] indicated that the release of IL-1 $\beta$, IL-6 and TNF- $\alpha$ stimulates lymphocytes to synthesize of IL-2. Due to above mentioned facts, Vink et al. [38] hypothesized that activation of central pruritus center in CNS and/or activation of central or peripheral opioid $\mu$-receptors, elevated serum level of IL-2, and may result in the even distribution of IL2 in UP in HD patients. On the other hand, Pereira and Dinarello [40] attributed the increase serum level of IL-2, which is normally produced by the body during an immune response, when environmental substances (molecules or microbes) gain access to the body. These substances that lead to increased level of IL-2 concentration could be due to the contact of blood with dialyzer membrane as suggested by Kimmel et al. [41]. Kimmel et al. [41] found that the contact of blood with dialyzer membrane leads to degranulation in leukocytes and release of inflammatory mediators. On the other hand, blood and dialyzer membrane interactions leads to the activation of monocytes, increased release of IL-1, IL-2 by the activated monocytes [42]. This constitutes a reasonable explanation of the results documented in our study.

This study observed a significant increase in of IL- 6 in pruritus patients and their hemodialysis patients control compared with that in healthy patients. The results of this study are similar to those reported by Carrero et al. [42], who documented high levels of interleukin (IL6) in HD patients with pruritus. Although the elevation of serum IL-6 is consistent with the results of Carrero [17] who contended that 'Numerous research studies on the synthesis and the release of prion flammatory cytokines IL- $1 \beta$, IL-2, IL-6, IL- 8 and TNF- $\alpha$ in patients with chronic renal failure on maintenance hemodialysis provide contradictory data", although some of these studies revealed increased serum levels of IL- 6 prior to and in the course of hemodialysis. However, according to Memoli et al. [43], there was a spontaneous elevation of IL- 6 and TNF- $\alpha$ by peripheral blood leukocytes in HD patients and there was an increased release of IL- 6 in the course of HD session. Engelberts et al. [44] Increased IL-6 serum levels in HD patients at each of the studied time points during hemodialysis session. This supports the findings of this study in that the concentration of IL- 6 in peripheral blood was increased in HD patients compared with non-renal failure patients or healthy individuals. The increased serum levels of IL-6 in pruritus patients observed in this study may have be attributed to in that 'Serum levels of inflammatory biomarkers such as IL-6 and white blood cell counts are also increased in patients with uremic pruritus.

The results of this investigation suggest that many factors may have important role in pathogenesis and progression of uremic pruritus from mild to severe. The association of histamine, cortisol, IL-2 and IL-6 are evident. Further research is needed to elucidate the main causes of UP, and association of serum biochemical values with its severity. The effect of the dialyzing membrane should be factored in any such investigation. The results of our study point out to the potential important role of both IL-2 and IL-6 in UP. Further studies are needed 
Citation: Shafei NKA, Nour A (2016) Observations on the Association of Serum histamine, Interleukins and Other Serum Biochemical Values with Severity of Pruritus in Chronic Hemodialysis Patients. J Nanomed Nanotechnol 7: 345. doi:10.4172/2157-7439.1000345

to investigate the contribution of histamine, IL-2 and IL-6, monocytes, and basophils on the development and severity of uremic pruritus, and the possible role of anti-IL-2 and IL-6 receptor antibodies in treatment of severe pruritus.

\section{Acknowledgement}

We would like to express our sincere gratitude to the Egyptian patients who signed the consent forms and participated in the study. Thanks are also extended to the staff of Artificial Kidney Unit and the clinical pathology lab of Benha University's hospital, Egypt, for their valuable help.

\section{References}

1. Mettang T, Pauli-Magnus C (2000) The pathophysiological puzzle of uremic pruritus-insights and speculations from therapeutic and epidemiological studies. Perit Dial Int 20: 493-494.

2. Mathur A, Baz ME, Staples DMD, Bonnell M, Jerry M, et al. (2006) Cytokine Profile After Lung Transplantation: Correlation With Allograft Injury. Ann ThoracSurg 5: 1844-1850.

3. Jacek Rysz, Maciej, Banach, Aleksandra, Cialkowska-Rysz, et al. (2006) Blood Serum Levels of IL-2, IL-6, IL-8, TNF-a and IL-1ß in Patients on Maintenance Hemodialysis.Cellular \& Molecular Immunology 2: 151-154.

4. Whicher JT, Evans SW (1990) Cytokines in disease. Clin Chem 36: 1269-1281

5. Descamps-Latscha B, Herbelin A, Nguyen AT, Roux-Lombard P, Zingraff J, et al. (1995) Balance between IL-1 beta, TNF-alpha, and their specific inhibitors in chronic renal failure and maintenance dialysis. Relationships with activation markers of T cells, B cells, and monocytes. J Immunol 154: 882-892.

6. Patton CJ, Crouch SR (1977) Spectrophotometric and kinetics investigation of the Berthelot reaction for the determination of ammonia. Anal Chem 49: 464-469.

7. Houort RL (1985) The estimation of plasma creatinine. Annual Biochem 53: 36-49.

8. Trinder $\mathrm{P}$ (1951) Photometric determination of serum sodium analyst 76: 596

9. Terri AE, Sesin PG (1958) Determination of serum potassium by using sodium tetraphenylboron. Am J Clin Path 2: 86-90.

10. Rubin JT (1993) Interleukin-2: its biology and clinical application in patients with cancer. Cancer Invest 11: 460-472.

11. Check JH (1995) Falsely elevated steroidal assay levels related to heterophile antibodies against various animal species. Gynecol Obstet Invest 2: 139-140.

12. Hermann K, Frank G, Ring J (1994) Contamination of heparin by histamine: measurement and characterization by high-performance liquid chromatography and radioimmunoassay. Allergy 49: 569-572.

13. Snedecor GW, Cochran G (1969) In stastical methods (6th edn.) Lowastote Unuv Press Anes Low USA

14. Narita I, Alchi B, Omori K, Sato F, Ajiro J, et al. (2006) Etiology and prognostic significance of severe uremic pruritus in chronic hemodialysis patients. Kidney Int 9: 1626.

15. Zahran N, Iman, William, Azza, Sayed, et al. (2012) Granulocyte Macrophage Colony Stimulating Factor Mediated Modulation of Polymorphonuclear Leukocyte Dysfunction in Chronic Kidney Disease and Hemodialysis Patients. Journal of American Science 6: 731-737

16. Arora PMD (2010) Chronic Renal Failure, Chief Editor: Vecihi Batuman, MD FACP, FASN: 1019-1226.

17. Carrero JJ, Witasp A, Stenvinkel P (2010) Visfatin is increased in chronic kidney disease patients with poor appetite and correlates negatively with fasting serum amino acids and triglyceride levels. Nephrol Dial Transplant Mar 3: 901-906.

18. Giebisch G, Wang W (1996) Potassium transport: from clearance to channels and pumps. Kidney Int 49: 1624-1631.

19. Bleyer AJ, Russell GB, Satko SG (1999) Sudden and cardiac death rates in hemodialysis patients. Kidney Int 55: 1553-1559.

20. Rose BD, Post TW (2001) Clinical Physiology of Acid-Base and Electrolyte Disorders (5th edn.) McGraw-Hill, New York: 383-396, 898-910.

21. Richard H, Sterns MD, Michael, Emmett MD, John P, et al. (2010) Causes of hyponatraemia version 19: 1 .
22. Rosa RM, Silva $P$, Young JB, Landsberg L, Brown RS, et al. (1980) Adrenergic modulation of extrarenal potassium disposal. N Engl J Med 302: 431-434.

23. Szepietowski J, Thepen T, van Vloten WA, Szepietowski T, Bihari IC, et al (1995) Pruritus and mast cell proliferation in the skin of haemodialysis patients. Inflamm Res 44 Suppl 1: S84-85.

24. Dugas-Breit $S$, Schöpf $P$, Dugas $M$, Schiffl $H$, Ruëff $F$, et al. (2005) Baseline serum levels of mast cell tryptase are raised in hemodialysis patients and associated with severity of pruritus. J Dtsch Dermatol Ges 3: 343-347.

25. Zhang JG, Lindup WE (1996) Role of calcium in cisplatin-induced cell toxicity in rat renal cortical slices. Toxicol In Vitro 10: 205-209.

26. Mukai K, Matsuoka K, Taya C, Suzuki H, Yokozeki H, et al. (2005) Basophils play a critical role in the development of IgE-mediated chronic allergic inflammation independently of T cells and mast cells. Immunity 23: 191-202.

27. Sokol CL, Barton GM, Farr AG, Medzhitov R (2008) A mechanism for the initiation of allergen-induced T helper type 2 responses. Nat Immunol 9: 310-318.

28. Mettang T, Fritz P, Weber J, Machleidt C, Hübel E, et al. (1990) Uremic pruritus in patients on hemodialysis or continuous ambulatory peritoneal dialysis (CAPD). The role of plasma histamine and skin mast cells. Clin Nephrol 34 136-141.

29. Ståhle-Bäckdahl M, Hägermark O, Lins LE (1988) The sensitivity of uremic and normal human skin to histamine. Acta Derm Venereol 68: 230-235.

30. Urbonas A, Schwartz RA, Szepietowski JC (2001) Uremic pruritus-an update. Am J Nephrol 21: 343-350.

31. Nasrollahi AR, Miladipour A, Ghanei E, Yavari P, Haghverdi F (2007) Montelukast for treatment of refractory pruritus in patients on hemodialysis. Iran J Kidney Dis 1: 73-77.

32. DimkoviÄ N, DjukanoviÄ L, RadmiloviÄ A, BojiÄ P, Juloski T (1992) Uremic pruritus and skin mast cells. Nephron 61: 5-9.

33. Bulent, Tokg Z, Alper ATA, Murat, SÜ,Oktay, OYMAK, Serap, UTAP, Cengiz, UTAP (2005): Effects of Oral Granisetron Treatment on uremic Pruritus. Turk J Med Sci 35 (2) 93-97.

34. Richardson BP (1990) Serotonin and nociception. Ann N Y Acad Sci 600: 511-519.

35. Tao Le, Bhushan V (2010) First Aid for the USMLE step 2 CS (clinical skills) McGraw Hill Publications.

36. Rosman PM, Benn R, Kay M, Wallace EZ (1984) Cortisol binding in uremic plasma. II. Decreased cortisol binding to albumin. Nephron 37: 229-231.

37. Fallahzadeh MK, Roozbeh J, Geramizadeh B, Namazi MR (2011) Interleukin-2 serum levels are elevated in patients with uremic pruritus: a novel finding with practical implications. Nephrol Dial Transplant 26: 3338-3344.

38. Vink A, Uyttenhove C, Wauters P, Van Snick J (1990) Accessory factors involved in murine $T$ cell activation. Distinct roles of interleukin 6 , interleukin 1 and tumor necrosis factor. Eur J Immunol 20: 1-6.

39. Smith KA (1988) Interleukin-2: inception, impact, and implications. Science 240: $1169-1176$

40. Pereira BJ, Dinarello CA (1994) Production of cytokines and cytokine inhibitory proteins in patients on dialysis. Nephrol Dial Transplant 9 Suppl 2: 60-71.

41. Kimmel M, Alscher DM, Dunst R, Braun N, Machleidt C, et al. (2006) The role of micro-inflammation in the pathogenesis of uraemic pruritus in haemodialysis patients. Nephrol Dial Transplant 21: 749-755.

42. Carrero JJ, Witasp A, Stenvinkel P, Qureshi AR, Heimbürger O, et al. (2010) Visfatin is increased in chronic kidney disease patients with poor appetite and correlates negatively with fasting serum amino acids and triglyceride levels. Nephrol Dial Transplant 25: 901-906.

43. Memoli B, Libetta C, Rampino T, De Simone W, Meccariello S, et al. (1991) Interleukin-6 production of uraemic haemodialysed patients: effects of different membranes. Nephrol Dial Transplant 6 Suppl 2: 96-98.

44. Engelberts I, Francot GJ, Leunissen KM, Haenen B, Ceska M, et al. (1994) Effect of hemodialysis on peripheral blood monocyte tumor necrosis factoralpha, interleukin-6, and interleukin-8 secretion in vitro. Nephron 66: 396-403. 